\title{
Effect of arginine on physiological and reproductive performance of Awassi ewes
}

\author{
T.R. Mohammed ${ }^{1 *}$, A.A. Al-Ani ${ }^{2}$ and A.A. Munther $^{1}$ \\ ${ }^{1}$ Animal Production, College Of Agriculture, University Of Anbar, Anbar, ${ }^{2}$ Office of Agricultural Research, Ministry of \\ Agriculture, Baghdad, Iraq, *email: ag.thair.rasheed@uoanbar.edu.iq
}

(Received May 29, 2018; Accepted December 12, 2018)

\begin{abstract}
The objective of the current study was to determine the effect of injected amino acid arginine on reproductive performance in ewes and on the levels of some hormones. Twenty-one non pregnant Awassi Turkish ewes were used. These ewes were divided into three equal groups. The first group were not treated which serve as control group (T1), and injected with 5-10 ml of normal saline in intramuscular. Ewes of second group (T2) were treated by injected with a $155 \mu \mathrm{mol} / \mathrm{kg}$ arginine I.V. The third group (T3) was treated by injected with $155 \mu \mathrm{mol} / \mathrm{kg}$ arginine intramuscular. All treated ewes were inseminated by rams for 7 days. Blood samples were taken from jugular vein on the 1st and 2nd days of arginine injection and then insert CIDR and on the $3^{\text {rd }}, 5^{\text {th }}, 7^{\text {th }}, 10^{\text {th }}, 13^{\text {th }}$, and $16^{\text {th }}$ days of this treatment to measure the change in the levels of some hormones during treatment. The results showed arithmetic difference in the time of the estrus where the treatment of intramuscular arginine injection came first and it was followed by intravenous arginine injection and then the control. Arginine treated groups significantly the control group in the estrus appearance rate. The estrus appearance estrus rate in intravenous injection group, intramuscular injection group and control group were $71.43,57.14$, and $42.85 \%$ respectively, also there is significant increase in fertility rates were $71.43,57.14$ and $42.85 \%$ respectively. There was a significant increase in pregnancy rates were 71.43 , 57.14 and $28.85 \%$ respectively. However, birth rates were $71.43,57.14$ and $28.57 \%$ respectively. Intravenous treatment showed the lowest than other treatments. The results of current research revealed no significant difference between groups in the level of progesterone hormone, furthermore there is no significant change in the hormone during all periods of the experiment except the $7^{\text {th }}$ period in IV arginine treated group. It was also observed a significant decrease in the estrogen concentration level in arginine intravenous $(14.62 \pm 1.02)$ and intramuscular $(15.00 \pm 1.98)$ injected groups in compared with control group $(16.82 \pm 1.25)$ respectively during the first and $7^{\text {th }}$ periods of injection after the insert of CIDR as compared with the other periods. There were no significant differences in the level of cortisol between the treated groups and the control group, and also between all periods of the experiment. It was concluded from this study that injection of amino acid arginine improved the reproductive performance of Awassi Turkish ewes, taking into consideration the superiority of intravenous injector as compared with intramuscular injection which gave higher rates of estrus, fertilization, fertility, pregnancy and birth and gave the lowest proportion of barrenness as compared with control group. However, arginine had no significant effects on the level of estrogen, progesterone and cortisol.
\end{abstract}

Keywords: Awassi ewes, Reproductive performance, Hormones Available online at http://www.vetmedmosul.com

$$
\begin{aligned}
& \text { تأثير الأرجنين في الأداء الفسلجي والإنتاجي للنعاج العواسي }
\end{aligned}
$$

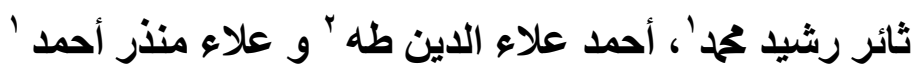

$$
\begin{aligned}
& \text { 'قسم الإنتاج الحيواني، كلية الزر اعة، جامعة الأنبار، الأنبار، ‘دائرة البحوث الزر اعية، وزارة الزر اعة، بغداد، العراق }
\end{aligned}
$$

الخلاصة

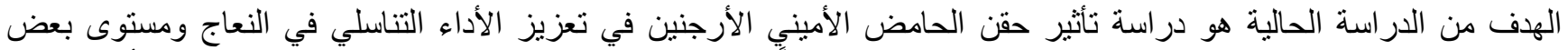

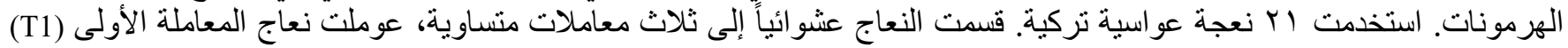




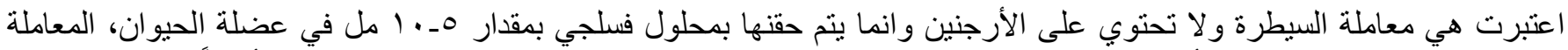

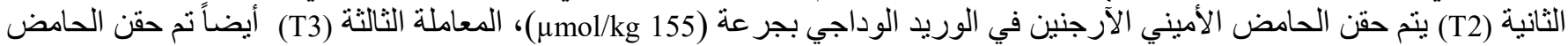

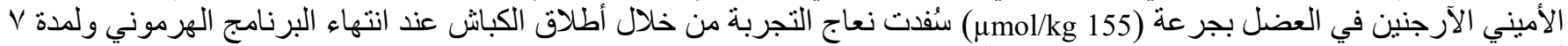

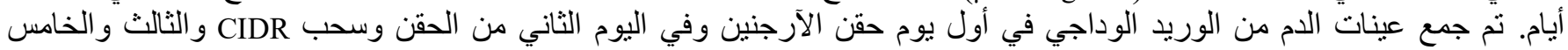

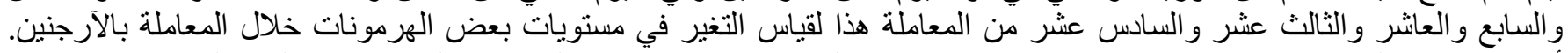

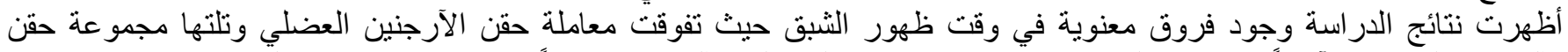

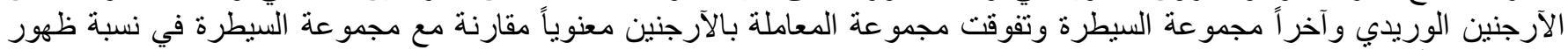

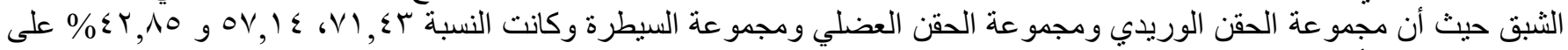

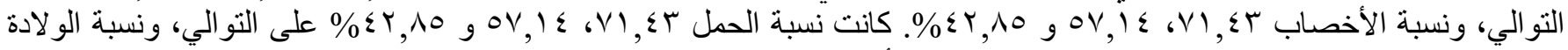

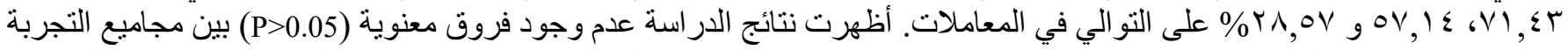

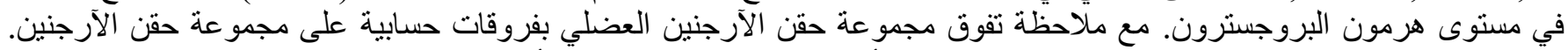

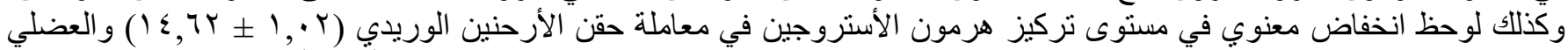

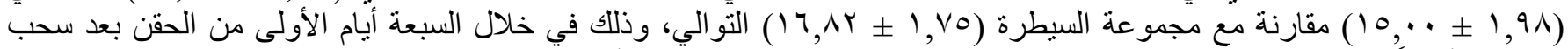

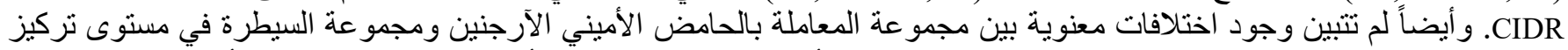

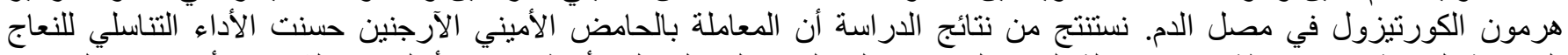

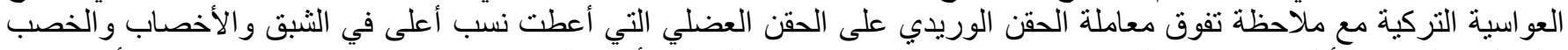

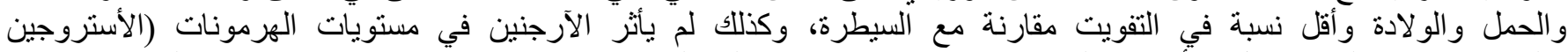

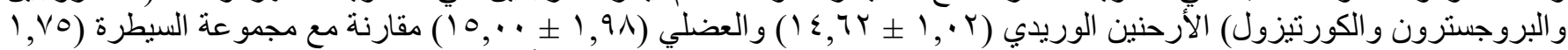

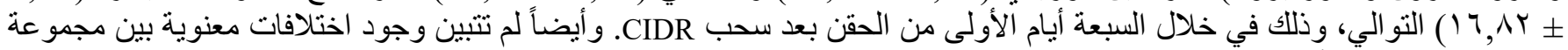

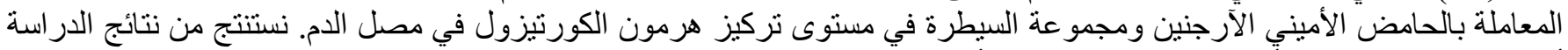

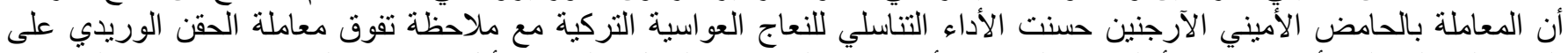

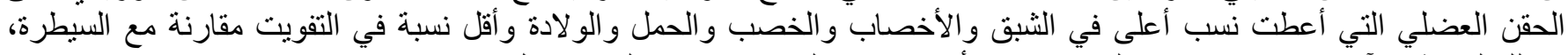

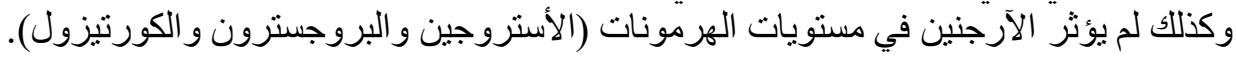

\section{Introduction}

The nutritional supplements have great importance for animals, they are defined as the minimum amount of nutrition in a balance provender needed by an animal to perform its body functions ideally, and each animal has its own needs which can vary according to its age, weight and the type of production. There are supporting of the nutritional needs of protein, energy, vitamins and amino acids necessary to keep Physiological operations regular inside the animal's body, this animal preservative provender does not lead to any increases or decreases in the animal weight (1). Due to the economic importance of sheep in the world in general and especially in Iraq, this has led researchers to pay attention on finding appropriate ways to promote this sector, whereas some researchers used the hormonal side (2). Some used the nutritional side $(3,4)$. Others focused on the biotechnological aspect $(5,6)$. There are several studies dealt with the using of dietary supplements which contain amino acids, including arginine, ornithine, and Citrulline. Recently, researchers have tended to study the effect of dietary supplements, including arginine because of its effective role in both human and animal health. In addition to the physiological importance of the production of $\mathrm{NO}$ which is produced throughout the metabolic chain inside the body. Nitric oxide has many functions and is involved in large-scale of physiological or pathological conditions inside the body where it dilates blood vessels (7). The vasodilation is a reaction to increase blood flow to the oligomers and tissues, which consequently leads to provide sufficient oxygen and nutrients to the cells via blood (8). These factors are important via improving of the uterine environment, which is regarded as the main aim to ensure a proper development of the placenta during early pregnancy (9). Studies on sheep have shown that the treatment of sheep with arginine enhances the functions of the parameters of reproduction, including the growth of the placenta and the embryo in different species $(10,11)$.

As a result of the importance of arginine in increasing reproductive performance and production qualities and due to little information about this study in Iraq. This study was aimed to show the effect of the arginine on reproductive performance including: time of estrus, the estrus rate, fertility rate, the pregnancy rate, the number of births, the number of twins furthermore the level estrogen, progesterone and cortisol hormones. 


\section{Materials and methods}

This Study was carried out in The Ruminant Research Station (Abu Ghraib)/ Department of Animal Resources / Office of Agricultural Research /Ministry of Agriculture during the period from July 6, 2017 to Feb 3, 2018. Twenty-one non pregnant Awassi Turkish ewes were used in the experiment. The age of the animals ranged between $2-5$ years old with a weight ranged between $45-70 \mathrm{~kg}$. The animals were examined with ultrasonography to be sure that they were not pregnant. These ewes were divided into three equal groups of 7 ewes. The treated groups were injected with arginine three times a day. The first group (T1) which was regarded as control group was injected with 5-10 ml of normal saline intramuscular. Ewes of second group (T2) were injected with a $155 \mu \mathrm{mol} / \mathrm{kg}$ arginine IV. The third group (T3) were injected with $155 \mu \mathrm{mol} / \mathrm{kg}$ arginine intramuscular (I.M). Insertion of CIDR has been done. The ewes were inseminated by rams for 7 days which were revolved among folds to get rid of ram's effect. Blood samples were taken from the jugular vein at the 1st, 2nd, $3 \mathrm{rd}, 5^{\text {th }}, 7^{\text {th }}, 10^{\text {th }}, 13^{\text {th }}$ and $16^{\text {th }}$ days of arginine injection to measure the changes in the level of (estrogen, progesterone and cortisol), Progesterone was measured by the ELISA and by German Intraassay by method Filicori (12), In the same way estrogen was measured by method of Tsang (13), and Cortisol was measured by ELISA and by American Monobind Kit during the treatment with arginine. Arginine used a product by (Bulk Supplements ${ }^{\mathcal{O}}$ Henderson, Nevada, USA).

\section{Statistical Analysis}

Two-way statistical analysis of variance in the hormones was used. It included the effects of the hormonal treatments and the time of pulling for each one separately on hormones characteristics during the hormonal treatment, by following the general linear model and using the SAS statistical program version (14). The differences between the averages were tested by using a multivariate (15) test. The percentages of reproductive performance were also analyzed by using chi - square test (16) at a significant level of 0.05 and 0.01 according to the mathematical model: $\mathrm{Yij}=\mu+\mathrm{Ti}+$ Eij.

\section{Results and discussion}

\section{Effect of arginine on reproductive traits Effect of arginine at the time of estrus}

The results showed the superiority of the arginine group regarding the time of the estrus a behavior as compared to the control group. It also showed the superiority of intramuscular injection upon the intravenous injection 23 and 31 hours respectively, as compared to the control group where the estrus appeared after 51 hours of injection (Table
1). This might be attributed to the activity of arginine through the increasing of blood flow to the genital organs, including ovaries and thus increasing the growth, development and promotion estrogen's level which has a role in the appearance of estrus's signs. This result agreed with Al-Dabbas (17) who showed where the level of estrogen in the arginine treated group. The delay in the onset of estrus behavior can be ascribed to the stress resulted from high temperature, which leads to the loss of appetite in the animal and thus reflects on the growth and development of follicles and the level of sex hormones (18).

\section{Effect of arginine in the estrus rate}

The results showed a significant increase $(\mathrm{P}<0.05)$ in estrus rate in arginine treated group as compared with control group (Table 1). It's worth mentioning that estrus rate in the intravenous arginine injection was significantly higher than in the intramuscular arginine injection, where the estrus rates in both treatments were $71.43 \%$ and $57.14 \%$, respectively, as compared with control group in which the estrus rate was $43.85 \%$. This may be ascribed to the activity of arginine amino acid in promoting blood flow to the reproductive organs and thus to release nitric oxide (NO) which help in expanding blood vessels and increasing the speed of blood flow to the organs (increasing nutrition and oxygen) (7). This result agreed with De Chávez and Crane $(19,20)$ who explained an increase in estrus rate in arginine, especially in intravenous injection which was higher than the control group. The rate of estrus appearance in the control treatment might be attributed to the CIDR tool application as indicated by Omontes (21) in his study. Where he observed a significant increase in the estrus rate in the CIDR group (progesterone) as compared with the control group (without CIDR).

\section{Effect of arginine on the fertility rate}

Table 1 demonstrated that injection of arginine (IM and IV) cause highly significant $(\mathrm{P}<0.05)$ in a fertility rate as compared with control group. It is observed that the fertilization rate in the intravenous arginine injection was significantly higher than that of the intramuscular injection, where they were $71.43 \%$ and $57.14 \%$, respectively, as compared with control group's rate which was $42.85 \%$. This may be ascribed to the activity of arginine in promoting blood circulation by releasing (NO), which helps in expanding blood vessels and thus increases the amount and speed of appropriate nutrients supplied to the reproductive organs during the implantation of fertilized eggs in the uterus where the uterine and embryonic membranes help in supplying nutrients and oxygen through the blood vessels from mother to fetus, this operation is important because it leads to increase the number of mature oocytes produced by ovaries during the period of estrus (22). The amino acid arginine- $\mathrm{HCl}$ has also many roles in the metabolism of the 
animal. It is considered as a base in protein synthesis (23). These results agreed with what was indicated by De Chávez (19). The results showed that giving arginine supplements during the final development of follicles, ovulation and early pregnancy improves fertility in ewes as well as improving fetal survival. In the same study, the results showed an increasing in fertility rate $87 \%$, in the arginine treatment.

\section{Effect of arginine on pregnancy rate}

From the Table 1 it is obvious that there was a significant increase $(\mathrm{P}<0.05)$ in pregnancy rate in arginine treated groups as compared with control group. It's worth mentioning that pregnancy rate in the intravenous injection was higher than it in the intramuscular injection where it was 71.43 and $57.14 \%$ respectively while it was $42.85 \%$ in the control group. The superiority of the two groups of arginine treatment over the control group may be ascribed to the effect of amino acid Arginine, where many studies have shown a critical role for the nitric oxide (No) in the expansion of blood vessels which leads to improve blood flow to the reproductive organs during pregnancy period and thus increase the amount of essential nutritious materials from mother to fetus by blood (24). The available evidences showed that both amines and nitric oxide (NO) plays a major role in vascular function are important and decisive during placental growth and fetal growth (25). They also, in advanced fetal stages, increase sizes and weights of infants and prevent fetuses losing (26). This may be also ascribed to the role of arginine in increasing the level of progesterone by promoting the function of the Corpus luteum. The increasing of the hormone level has an important role in the maintenance of pregnancy. Many studies have shown that low level of hormone (P4) can lead to a large proportion of fetus losses in sheep (9). These results agreed with Saevre (27). The pregnancy rate was higher in ewes injected with arginine $57 \%$ as compared with control treated ewes, where the pregnancy rate was $30 \%$.

\section{Effect of arginine in birth rate}

The results of current study showed a significant increase (.in the birth rate in arginine treated groups compared with control group They also showed that birth rate in intravenous arginine injection was higher than in the intramuscular arginine injection where it was $71.43 \%$ and $57.14 \%$ respectively, while it was $28.57 \%$ in control group (Table 1). This might be due to that arginine injection increased the quantity of nutrients carried to the body organs including the reproductive organs. (10) Clarified that arginine injection during the period of Corpus luteum formation led to increase the growth and development of the Corpus luteum and thus promote the work of progesterone and thus maintain pregnancy. The superiority of the treatment of Arginine with IV. injection over the arginine intramuscular injection might be attributed to the effect of Arginine injection which was agreed with Richard (28) that observed, the intravenous injection is the fastest way to carry drugs into the blood circulation. These results were in consistent with Saevre (27) who clarified that injecting ewes with the arginine during the gestation period in sheep, improved survival rate to $24 \%$. Which negatively affected the appetite of the animal which consequently led to decrease the level of hormones due to the weakness of follicles and the Corpus luteum development and therefore a low birth rate. This observation might be in consistent with Takahashi (18) who pointed out where he clarified that heat stress had harmful effects on nutritional, physiological and reproductive functions, leading to decrease pregnancy rate after vaccination as well as losing of embryos. However, it is also effects on the body weight, milk production as well as reproductive performance of both sexes.

\section{Effect of arginine on the twining rate}

The data of research revealed a significant increase $(\mathrm{P}<0.05)$ in twin rate which was $20 \%$ in IV injected arginine group as compared with control and IM injected groups (Table 1). These results might be attributed to the nature of the treatment where the intravenous injection carrying medicines faster rather than other treatments (28). This agreed with Fierro (29) who observed that injecting LArginine $\mathrm{HCl}$ led to increase blood flow to the ovaries and developing follicles carrying big quantities of nutrients which leads to increase ovarian efficiency and stimulate follicular growth during the final development of follicle, ovulation and early pregnancy which is reflected in increasing fetal survival and their numbers.

\section{Effect of arginine on the Barrenness rate}

The results showed a significant decrease $(\mathrm{P}<0.05)$ in barrenness rate in the arginine IV injected group as compared with control group. (Table 1). It was also observed that barrenness rate in intravenous injection was lower than in intramuscular injection which was $28.57 \%$ and $42.85 \%$, respectively while it was $71.42 \%$ in control group. This might be attributed to the arginine efficiency in increasing the blood flow to the body organs, including the ovaries, where it reduces apoptosis of cells and thus increases the efficiency of the follicles and the Corpus luteum (30), This agreed with Fierro (29) who indicated that increasing blood flow was followed by an increasing in the growth, developing and enhancement of estrogen level, as well as large quantity of nutrients which leads in its turn to increase ovarian efficiency and stimulate follicles' growth during the final development of follicle and ovulation and early pregnancy, and this reflected on increasing fetal survival. 
Table 1: Effect of arginine on reproductive performance in ewes

\begin{tabular}{|c|c|c|c|c|}
\hline \multirow{2}{*}{ Adjective } & \multicolumn{3}{|c|}{ Treatment } & \multirow{2}{*}{$\begin{array}{c}\text { Kay } \\
\text { square } \\
\text { value }\left(x^{2}\right)\end{array}$} \\
\hline & $\mathrm{T} 1$ & $\mathrm{~T} 2$ & $\mathrm{~T} 3$ & \\
\hline Total ewes & 7 & 7 & 7 & --- \\
\hline Time of estrus (h) & 51 & 31 & 23 & --- \\
\hline Appearance of estrus & 3 & 5 & 4 & --- \\
\hline Estrus rate $(\%)$ & 42.85 & 71.43 & 57.14 & $9.522 * *$ \\
\hline No. of pregnant ewes & 2 & 5 & 4 & --- \\
\hline No. of ewe births & 2 & 5 & 4 & --- \\
\hline Fertility rate (\%) & 42.85 & 71.43 & 57.14 & $9.522 * *$ \\
\hline Fecundity & 0,28 & 0.85 & 0.57 & --- \\
\hline The litter size & 1 & 1,2 & 1 & --- \\
\hline Pregnancy rate (\%) & 42.85 & 71.43 & 57.14 & $9.522 * *$ \\
\hline No. of Twin Births & 0 & 1 & 0 & --- \\
\hline Birth rate $(\%)$ & 28.57 & 71.43 & 57.14 & $12.073 * *$ \\
\hline Twinning rate (\%) & 0 & 20 & 0 & $8.250 * *$ \\
\hline Barrenness rate $(\%)$ & 71.43 & 28.57 & 42.85 & $9.522 * *$ \\
\hline
\end{tabular}

Effect of arginine on the concentration of hormones The effect of arginine on the concentration of estrogen

The results of current study showed no significant differences $(\mathrm{P}>0.05)$ in estrogen level between the arginine treated group and the control group except at the period 1 $\left(1^{\text {st }}\right.$ day) and $5\left(7^{\text {th }}\right.$ days $)$ where the results showed the Superiority of arginine treated groups as compared with the control group (Table 2). In other periods, it was observed that there were only mathematical differences among treatments. There were no significant differences $(\mathrm{P}>0.05)$ between arginine intravenous injection and arginine intramuscular injection on estrogen level. But in general, it was observed that the level of estrogen reduced as periods progressed and this agreed with Youngquist (31) who indicated that the level of estrogen decreases with increasing the level of progesterone. The value of estrogen significantly increased $(\mathrm{P}<0.05)$ in arginine treated group at the periods 5 as compared with control group while the level of estrogen in control group decreased significantly and gradually at the $2^{\text {nd }}, 3^{\text {th }}, 4^{\text {th }}$ and $5^{\text {th }}$ periods compared with $1^{\text {st }}$ period and the value of hormone at the $6^{\text {th }} .7^{\text {th }}$, and $8^{\text {th }}$ periods became as same as the $1^{\text {st }}$ period. Regarding the effect of pulling time on concentration of estrogen within the same treatment, this result was coincided with progesterone decrease in the current research (Table 3). The results of the arginine intravenous injected group showed a gradual and significant increase at the period $5^{\text {th }}, 6^{\text {th }}$ and the highest level at $7^{\text {th }}(18.22 \pm 1.06 \mathrm{pg} / \mathrm{ml})$ of the experiment. But in intramuscular injection group, the highest level of estrogen concentration was at the period $6^{\text {th }}$ where it was $(17.10 \pm 1.51 \mathrm{pg} / \mathrm{ml})$. These results agreed with Al-Dabbas (17) who indicated that the level of estrogen was constantly variable but there was a clear increasing trend in the level of estrogen in the arginine group as compared with the control group. This was coincided with an increase in the rate of ovulation and levels of progesterone $(\mathrm{P}<0.01)$ compared with the control group which may be attributed to the pregnancy while the disparity in the secretion of estrogen may be ascribed to the follicular growth and developing before reaching full maturity (32).

Table 2: Effect of arginine in the level of serum estrogen $(\mathrm{pg} / \mathrm{ml})$ in Awassi ewes

\begin{tabular}{cccc}
\hline \multirow{2}{*}{ Period } & \multicolumn{3}{c}{ Treatment } \\
\cline { 2 - 4 } & $\mathrm{T} 1$ & $\mathrm{~T} 2$ & $\mathrm{~T} 3$ \\
\hline \multirow{2}{*}{$1\left(1^{\text {st }}\right.$ day $)$} & $16.82 \pm 1.25$ & $14.62 \pm 1.02$ & $15.00 \pm 1.98$ \\
& $\mathrm{~A} \mathrm{a}$ & $\mathrm{B} \mathrm{ab}$ & $\mathrm{B} \mathrm{abc}$ \\
$2\left(2^{\text {nd }}\right.$ day $)$ & $12.10 \pm 1.26$ & $16.5 \pm 1.48$ & $14.54 \pm 1.15$ \\
& $\mathrm{~A} \mathrm{~cd}$ & $\mathrm{~A} \mathrm{ab}$ & $\mathrm{A} \mathrm{bc}$ \\
$3\left(3^{\text {rd }}\right.$ day $)$ & $11.55 \pm 1.35$ & $12.22 \pm 1.95$ & $13.37 \pm 1.26$ \\
& $\mathrm{~A} \mathrm{~d}$ & $\mathrm{~A} \mathrm{~b}$ & $\mathrm{~A} \mathrm{bc}$ \\
$4\left(5^{\text {th }}\right.$ day $)$ & $13.9 \pm 1.50$ & $12.30 \pm 0.53$ & $15.02 \pm 1.47$ \\
& $\mathrm{~A} \mathrm{bcd}$ & $\mathrm{A} \mathrm{b}$ & $\mathrm{A} \mathrm{bc}$ \\
$5\left(7^{\text {th }}\right.$ day $)$ & $10.57 \pm 0.56$ & $1.6116 .88 \pm$ & $16.18 \pm 1.60$ \\
& $\mathrm{~B} \mathrm{~d}$ & $\mathrm{~A} \mathrm{a}$ & $\mathrm{A} \mathrm{ab}$ \\
$6\left(10^{\text {th }}\right.$ day $)$ & $17.37 \pm 1.34$ & $17.82 \pm 2.18$ & $17.10 \pm 1.51$ \\
& $\mathrm{~A} \mathrm{ab}$ & $\mathrm{A} \mathrm{a}$ & $\mathrm{A} \mathrm{a}$ \\
$7\left(13^{\text {th }}\right.$ day $)$ & $16.81 \pm 1.34$ & $18.22 \pm 1.06$ & $11.51 \pm 0.92$ \\
& $\mathrm{~A} \mathrm{ab}$ & $\mathrm{A} \mathrm{a}$ & $\mathrm{A} \mathrm{c}$ \\
$8\left(16^{\text {th }}\right.$ day $)$ & $16.07 \pm 14.2$ & $15.34 \pm 0.98$ & $13.15 \pm 1.03$ \\
& $\mathrm{~A} \mathrm{abc}$ & $\mathrm{A} \mathrm{ab}$ & $\mathrm{A} \mathrm{bc}$ \\
\hline
\end{tabular}

* Values represent the average \pm standard error. The different capitals within the same row indicate significant differences between the coefficients. The different small letters within the same column indicate that there are significant differences between the clouds within the single treatment at a significant level $(\mathrm{P}<0.05)$.

\section{Effect of arginine on the concentration of progesterone}

The results showed no significant differences $(\mathrm{P}>0.05)$ between the arginine treated groups and control group in the level of progesterone (Table 3). The results also showed that progesterone levels at the beginning of the period were high, which agreed with Ibrahim (33) and Moura (34), who showed that the progesterone concentration was high in females, when the progesterone tool was inserted in their vagina as compared with the females not treated with progesterone tool. It is relatively decreased in pre-ovulation period, then it increased after ovulation $(<5 \mathrm{ng} / \mathrm{ml})$. This indicates pregnancy while the levels of progesterone were maintained at the beginning periods $1,2,3$, and 4 at the levels of the Corpus luteum, but with the beginning of zerosal-placenta stage, an increase in the level of progesterone was observed in order to keep pregnancy. Regarding the effects of pulling time. The data of the first 
treatment recorded not significant lowest level of progesterone concentration at period 3 where its level was $4.51 \pm 0.11 \mathrm{ng} / \mathrm{ml}$ then it increased not significant to the highest value at the period 6 which reached $5.62 \pm 0.25$ $\mathrm{ng} / \mathrm{ml}$ then the variance disappeared in the rest of the periods. In the arginine treated group, it was observed that the concentration of the hormone increased gradually and not significantly to a highest value at the period 8 in the intravenous injection and intramuscular injection treatment, progesterone hormone concentration $6.14 \pm 0.35$ and $6.11 \pm$ $0.25 \mathrm{ng} / \mathrm{ml}$ respectively. The results of the current study agreed with Saevre (27) who indicated that the progesterone concentrations in the ewes treated with arginine via intravenous injections were lower than it in the control ewes on day $9^{\text {th }}$ and $10^{\text {th }}$ of pregnancy, but they were equal in the remaining periods. The results also agreed with Luther (10) indicated that the level of progesterone concentration was higher in ewes treated with arginine though there were no significant differences as compared with control group. The arginine group also didn't vary significantly $(\mathrm{P}>0.05)$ from control treatment in the numbers of Corpus luteum (control $1.8 \pm 0.199$ and Arg $1.8 \pm 0.12$ ) and in the pregnancy rate (control 60\% and Arg 55\%) but the number of embryos in the arginine treated group was higher $(\mathrm{P}<0.05)$ at $25^{\text {th }}$ day of pregnancy. The reason of increasing the number of embryos might be attributed to that arginine promotes the uterine environment more ideal for keeping and preserving embryos by supplying them with nutrition as well as raising the level of progesterone which is necessary to maintain pregnancy.

\section{Effect of arginine on cortisol concentration}

The results (Table 4) showed no significant differences $(\mathrm{P}>0.05)$ between the arginine treated groups and control group in serum cortisol concentration. On the ewes treated with arginine were characterized by increased activity compared to control treatment. This might be due to the role of arginine by increasing blood circulation to internal organs and thus increasing its effectiveness and function. The rise of cortisol in the experimental process put ewes under the stress, but the arginine worked to reduce the impact of stress due to increased blood roses to the body members. Tilbrook (35) indicated that under stress conditions, when the cortisol level in ejaculatory serum was high, the reduced reproductive potential was likely to reduce the chance of copulation with rams or to copulate several times, which is often necessary to achieve pregnancy. The results agreed with Papargiris (36) who indicated that injection of cortisol in ewes reduced the acceptance behavior of ewes, as compared to ewes injected with brine. The results of study agreed with what mentioned above that chronic injections of cortisol reduce genital response (37).
Table 3: Effect of arginine in the level of progesterone in serum $(\mathrm{ng} / \mathrm{ml})$ in Awassi ewes

\begin{tabular}{cccc}
\hline \multirow{2}{*}{ Period } & \multicolumn{3}{c}{ Treatment } \\
\cline { 2 - 4 } & $\mathrm{T} 1$ & $\mathrm{~T} 2$ & $\mathrm{~T} 3$ \\
\hline \multirow{2}{*}{$1\left(1^{\text {st }}\right.$ day $)$} & $5.12 \pm 0.55$ & $4.57 \pm 0.40$ & $5.54 \pm 0.56$ \\
& $\mathrm{~A} \mathrm{a}$ & $\mathrm{A} \mathrm{ab}$ & $\mathrm{A} \mathrm{a}$ \\
$2\left(2^{\text {nd }}\right.$ day $)$ & $5.42 \pm 0.31$ & $4.87 \pm 0.47$ & $4.27 \pm 0.47$ \\
& $\mathrm{~A} \mathrm{a}$ & $\mathrm{A} \mathrm{ab}$ & $\mathrm{A} \mathrm{b}$ \\
$3\left(3^{\text {rd }}\right.$ day $)$ & $5.11 \pm 0.25$ & $4.85 \pm 0.19$ & $4.51 \pm 0.11$ \\
& $\mathrm{~A} \mathrm{a}$ & $\mathrm{A} \mathrm{ab}$ & $\mathrm{A} \mathrm{b}$ \\
$4\left(5^{\text {th }}\right.$ day $)$ & $4.91 \pm 0.17$ & $4.94 \pm 0.21$ & $4.81 \pm 0.24$ \\
& $\mathrm{~A} \mathrm{a}$ & $\mathrm{A} \mathrm{ab}$ & $\mathrm{A} \mathrm{ab}$ \\
$5\left(7^{\text {th }}\right.$ day $)$ & $5.25 \pm 0.61$ & $5.52 \pm 0.28$ & $4.91 \pm 0.86$ \\
& $\mathrm{~A} \mathrm{a}$ & $\mathrm{A} \mathrm{a}$ & $\mathrm{A} \mathrm{a}$ \\
$6\left(10^{\text {th }}\right.$ day $)$ & $6.04 \pm 0.25$ & $5.27 \pm 0.28$ & $5.62 \pm 0.25$ \\
& $\mathrm{~A} \mathrm{a}$ & $\mathrm{A} \mathrm{ab}$ & $\mathrm{A} \mathrm{a}$ \\
$7\left(13^{\text {th }}\right.$ day $)$ & $5.41 \pm 0.30$ & $5.30 \pm 0.42$ & $4.97 \pm 0.14$ \\
& $\mathrm{~A} \mathrm{a}$ & $\mathrm{A} \mathrm{b}$ & $\mathrm{A} \mathrm{ab}$ \\
$8\left(16^{\text {th }}\right.$ day $)$ & $6.11 \pm 0.25$ & $6.14 \pm 0.35$ & $5.30 \pm 0.23$ \\
& $\mathrm{~A} \mathrm{a}$ & $\mathrm{A} \mathrm{ab}$ & $\mathrm{A} \mathrm{ab}$ \\
\hline
\end{tabular}

* Values represent the average \pm standard error. The different capitals within the same row indicate significant differences between the coefficients. The different small letters within the same column indicate that there are significant differences between the clouds within the single treatment at a significant level $(\mathrm{P}<0.05)$.

Table 4: Effect of arginine in the level of serum cortisol $(\mathrm{ng} / \mathrm{ml})$ in Awassi ewes

\begin{tabular}{cccc}
\hline \multirow{2}{*}{ Period } & \multicolumn{3}{c}{ Treatment } \\
\cline { 2 - 4 } & $\mathrm{T} 1$ & $\mathrm{~T} 2$ & $\mathrm{~T} 3$ \\
\hline \multirow{2}{*}{$2\left(2^{\text {nd }}\right.$ day $)$} & $12.14 \pm 0.70$ & $11.28 \pm 0.71$ & $12.10 \pm 0.34$ \\
& $\mathrm{~A} \mathrm{a}$ & $\mathrm{A} \mathrm{a}$ & $\mathrm{A} \mathrm{a}$ \\
$4\left(5^{\text {th }}\right.$ day $)$ & $10.71 \pm 0.94$ & $9.85 \pm 0.70$ & $9.42 \pm 0.48$ \\
& $\mathrm{~A} \mathrm{a}$ & $\mathrm{A} \mathrm{a}$ & $\mathrm{A} \mathrm{b}$ \\
$6\left(10^{\text {th }}\right.$ day $)$ & $10.71 \pm 0.52$ & $9.57 \pm 0.93$ & $10.28 \pm 0.60$ \\
& $\mathrm{~A} \mathrm{a}$ & $\mathrm{A} \mathrm{a}$ & $\mathrm{A} \mathrm{b}$ \\
$8\left(16^{\text {th }}\right.$ day $)$ & $10.28 \pm 0.56$ & $9.57 \pm 0.52$ & $10.57 \pm 0.48$ \\
& $\mathrm{~A} \mathrm{a}$ & $\mathrm{A} \mathrm{a}$ & $\mathrm{A} \mathrm{ab}$ \\
\hline
\end{tabular}

* Values represent the average \pm standard error. The different capitals within the same row indicate significant differences between the coefficients. The different small letters within the same column indicate that there are significant differences between the clouds within the single treatment at a significant level $(\mathrm{P}<0.05)$.

\section{Acknowledgement}

We would like to express our deepest respect to the dean of the College of Agriculture and Animal Production, 
University of Anbar for his help and assistant in complete this study. Also, great thanks should be sent to the Office of Agricultural Research / Ministry of Agriculture for his help and assistant.

\section{References}

1. Wu G. Principles of animal nutrition. $1^{\text {st }}$. New York: CRC Press; 2018. 151, 177, $666 \mathrm{p}$.

2. Guesdon V, Meurisse M, Chesneau D, Picard S, Lévy F, Chaillou E. Behavioral and endocrine evaluation of the stressfulness of single-pen housing compared to group-housing and social isolation conditions. Physiol Behav. 2015;147;63-70. doi.org/10.1016/j.physbeh. 2015.04.013

3. Ellison MJ, Conant GC, Lamberson WR, Cockrum RR, Austin KJ, Rule DC, Cammack KM. Diet and feed efficiency status affect rumen microbial profiles of sheep. Small Rumin Res. 2017;156:12-19. doi.org/10.1016/j.smallrumres.2017.08.009

4. Singh R, Bal MS, Singla LD, Kaur P. Detection of anthelmintic resistance in sheep and goat against fenbendazole by faecal egg count reduction test. J Parasit Dis. 2017;41(2):463-466. doi.org/10.1007/s12639-016-0828-8

5. Mirzaei A, Mohebbi-Fani M, Omidi A, Boostani A, Nazifi S, Mahmoodian-Fard HR, Chahardahcherik M. Progesterone concentration and lambing rate of Karakul ewes treated with prostaglandin and GnRH combined with the ram effect during breeding and non-breeding seasons. Theriogen. 2017;100:120-125. doi.org/10.1016/j.theriogenology.2017.06.005

6. Bruno-Galarraga $\mathrm{M}$, Cueto $\mathrm{M}$, Gibbons A, Pereyra-Bonnet $\mathrm{F}$, Subiabre M, González-Bulnes A. Preselection of high and low ovulatory responders in sheep multiple ovulation and embryo transfer programs. Theriogen. 2015;84(5):784-790. doi.org/10.1016/j.theriogenology.2015.05.011

7. Wu G, Bazer FW, Davis TA, Kim SW, Li P, Rhoads JM, Yin Y Arginine metabolism and nutrition in growth, health and disease. Amino Acid. 2009;37(1):153-168. doi.org/10.1007/s00726-008-0210y.

8. McConell, GK. Effects of L-arginine supplementation on exercise metabolism. Curr Opin Clini Nutr Metabo Care. 2007;10(1):46-51. doi: 10.1097/MCO.0b013e32801162fa.

9. Spencer, TE, Johnson, GA, Burghardt RC, Bazer FW. Progesterone and placental hormone actions on the uterus: insights from domestic animals. Bio $\quad$ Rep. 2004;71(1):2-10. doi.org/10.1095/biolreprod.103.024133.

10. Luther, JS, Windorski EJ, Caton JS, Wu G, Kirsch JD, Vonnahme KA, Schauer CS. Effects of arginine supplementation on reproductive performance in Rambouillet ewes. Sheep Res Rep. 2009;50:11-13. DOI: $10.13140 / 2.1 .3744 .3367$

11. Lassala A, Bazer FW, Cudd TA, Datta S, Keisler DH, Satterfield MC, Wu G. Parenteral administration of L-arginine enhances fetal survival and growth in sheep carrying multiple fetuses. J Nutri. 2011;141(5):849-855. doi.org/10.3945/jn.111.138172.

12. Filicori M, Butler JP, Crowley WF. Neuroendocrine regulation of the corpus luteum in the human. J Clin Invest. 1984;73:1638-1642. doi.org/10.1172/JCI111370.

13. Tsang BK, Armstrong DT, Whitfield JF. Steroid biosynthesis by isolated human ovarian follicular cells in vitro. J Clin Endoc Metab. 1980;51:1407-1411. doi.org/10.1210/jcem-51-6-1407

14. Statistical Analysis Systems User's Guide (SAS). North Carolina: SAS Institute Inc. 2003

15. Steel RGD, Torrie JH. Principles procedures of statistics. New York: McGraw - Hill Book Company. 1960. 481 p..

16. Duncan D. B. Multiple range and multiple $\mathrm{F}$ tests. Biometrics. 1955;11(1):1-42. DOI: $10.2307 / 3001478$
17. Al-Dabbas FM, Hamra AH, Awawdeh FT. The effect of arginine supplementation on some blood parameters, ovulation rate and concentrations of estrogen and progesterone in female Awassi sheep. Pakistan J Biol Sci. 2008;11(20):2389-2394. DOI: 10.3923/pjbs.2008.2389.2394

18. Takahashi M. Heat stress on reproductive function and fertility in mammals. Rep Med Biol. 2012;11(1):37-47. doi.org/10.1007/s12522011-0105-6.

19. De Chávez JAR, Guzmán A, Zamora-Gutiérrez D, Mendoza GD, Melgoza LM, Montes S, Rosales-Torres AM. Supplementation with rumen-protected L-arginine- $\mathrm{HCl}$ increased fertility in sheep with synchronized estrus. Trop Ani Heal Prod. 2015;47(6):1067-1073. doi.org/10.1007/s11250-015-0833-4.

20. Crane AR, Redden RR, Van Emon ML, Neville, TL, Reynolds LP, Caton JS, Schauer CS. Impacts of supplemental arginine on the reproductive performance of fall lambing ewes. J Amin Sci. 2016;94(8):3540-3549. doi.org/10.2527/jas.2016-0379.

21. Omontese BO, Rekwot PI, Makun HG, Obidi JA, Ruwaan JS, Chiezey NP. Synchronization of estrus using EAZI-Breed CIDR and FGA-30 intravaginal sponge in PrePartum Yankasa Ewes. Res J Anim Sci. 2010;4(1):53-57. DOI: 10.3923/rjnasci.2010.53.57.

22. Bazer FW, Spencer TE, Johnson GA, Burghardt RC. Uterine receptivity to implantation of blastocysts in mammals. Front Biosci. 2011; 3; 745-767. DOI: 10.2741/s184.

23. Wu G, Bazer FW, Burghardt RC, Johnson GA, Kim SW, Li XL, Spencer TE. Impacts of amino acid nutrition on pregnancy outcome in pigs: Mechanisms and implications for swine production. J Amin Sci. 2010;88(13):e195-e204. doi.org/10.2527/jas.2009-2446.

24. Sladek SM, Magness RR, Conrad KP. Nitric oxide and pregnancy. Amer J Physiol Integra Comp Physiol. 1997;272(2):r441-r463. doi.org/10.1152/ajpregu.1997.272.2.R441.

25. McPherson JP, Tamblyn L, Elia A, Migon E, Shehabeldin A, Matysiak-Zablocki E, Kassam, F. Lats $2 / \mathrm{Kpm}$ is required for embryonic development, proliferation control and genomic integrity. EMBO J. 2004;23(18):3677-3688. doi.org/10.1038/sj.emboj.7600371.

26. Grazul-Bilska AT, Borowicz PP, Johnson ML, Minten MA, Bilski JJ, Wroblewski R, Reynolds LP. Placental development during early pregnancy in sheep: vascular growth and expression of angiogenic factors in maternal placenta. Rep. 2010;140(1):165-174. doi.org/10.1530/REP-09-0548.

27. Saevre C, Meyer AM, Van Emon ML, Redmer DA, Caton JS, Kirsch JD, Schauer CS. Impacts of arginine on ovarian function and reproductive performance at the time of maternal recognition of pregnancy in ewes. NDSU Sheep Res Rep. 2011;52:13-16. org/c540/63c9f5742fd22198d92d5cf367aed3343f01.pdf.

28. Richard A. Harvey MA, Clark R, Finkel JA, Rey KW, Lippincott W, Wilkins. Lippincott's Illustrated Reviews: Pharmacology. 5th. Philadelphia: Wolters Kluwer Health/Lippincott Williams \& Wilkins; 2012. 3 p..

29. Fierro S, Gil J, Vinoles C, Olivera-Muzante J. The use of prostaglandins in controlling estrous cycle of the ewe: A review. Therio. doi.org/10.1016/j.theriogenology.2012.10.022.

30. Herring CM, Bazer FW, Johnson GA, Wu G. Impacts of maternal dietary protein intake on fetal survival, growth, and development. Experi Bio Med. 2018;243(2):525-533. doi: $10.1177 / 1535370218758275$.

31. Youngquist RS. Threlfall WR. Current therapy in large animal theriogenology. $2^{\text {nd }}$. New York: Elsvier; 2007. 106 p..

32. Ginther OJ, Knopf L, Kastelic JP. Temporal associations among ovarian events in cattle during estrous cycles with two and three follicular waves. J Rep Fer. 1989;87(1):223-230. DOI: 10.1530/jrf.0.0870223. doi.org/10.1530/jrf.0.0870223.

33. Ibrahim NS. Serum FSH, LH and progesterone hormones concentrations in relation to hormonal estrous induced, laparoscopical insemination and pregnancy in non-breeding season in Iraqi goats. Online Inter Disciplinary Res. 2013;3(5):54-59. DOI: 20143097784 
34. Moura RR, Souza JMG, Fonseca JF, Melo CHS, Sanchez DJD, MP, Vieira TM, Almeida IA, Serova OL, Serov AF, Pereira DIA, Teixeira LM, Melo VJF, Freitas. Reproductive parameters and the use of MOET in transgenic founder goat carrying the human granulocyte colony-stimulating factor (hG-CSF) gene. Anim Reprod. 2014;11(1):37-43. org/article/5b5a6044f7783717068b4676.

35. Tilbrook AJ, Cameron AWN, Lindsay DR. The influence of ram mating preferences and social interaction between rams on the proportion of ewes mated at field joining. Appl Anim Behav Sci. 1987;18(2):173-184. doi.org/10.1016/0168-1591(87)90191-2.
36. Papargiris MM, Rivalland ETA, Hemsworth PH, Morrissey AD, Tilbrook AJ. Acute and chronic stress-like levels of cortisol inhibit the oestradiol stimulus to induce sexual receptivity but have no effect on sexual attractivity or proceptivity in female sheep. Horm Behav. 2011;60(4):336-345. doi.org/10.1016/j.yhbeh.2011.06.008.

37. Pierce BN, Hemsworth PH, Rivalland ETA, Wagenmaker ER, Morrissey AD, Papargiris MM, Tilbrook AJ. Psychosocial stress suppresses attractivity, proceptivity and pulsatile LH secretion in the ewe. Horm Behav.
doi.org/10.1016/j.yhbeh.2008.04.005. 